\title{
In Search of Primary Source Literacy: Opportunities and Challenges
}

THE INCREASING EMPHASIS ON primary source research is causing cultural heritage professionals to look at how to assess the effectiveness of their teaching. ${ }^{2}$ The need to evaluate teaching has in turn caused some to wonder what it is exactly that we hope to assess. The term "primary sources" can itself be defined in a variety of ways. In this paper, primary sources "provide first-hand testimony or direct evidence concerning a topic under investigation." ${ }^{3}$ They include rare books, photographs, diaries, personal papers, and a wide variety of other material types. There have also been proposed a range of definitions attempting to define the skills required to work effectively with these materials. The lack of community-defined standards and learning outcomes has made it more difficult for cultural heritage professionals to effectively teach students to read and understand primary sources. In the same way that the other segments of the library community have developed guidelines for teaching general and specialized information literacy skills, guidance for teaching primary source literacy is also needed.

Primary source literacy as a concept has relatively recent origins for archivists, with Elizabeth Yakel initiating the discussion in $2004 .{ }^{4}$ However, museum professionals have discussed these ideas for decades, coining the phrase "museum literacy" in the early 1980s. ${ }^{5}$ Special collections librarians have also had a history of engaging with the issues of primary source literacy—particularly in the context of teaching with

1. Portions of this paper were presented at the 54th annual RBMS Preconference in Minneapolis, Minnesota.

2. Anne Bahde and Heather Smedberg, "Measuring the Magic: Assessment in the Special Collections and Archives Classroom," RBM: A Journal of Rare Books, Manuscripts and Cultural Heritage 13, no. 2 (Fall 2012): 152-74; Magia Krause, "Learning in the Archives: A Report on Instructional Practices," Journal of Archival Organization 6, no. 4 (2008): 233-68; Morgan Daniels and Elizabeth Yakel, "Uncovering Impact: The Influence of Archives on Student Learning," Journal of Academic Librarianship (2013), available online at http:/ / dx.doi.org/10.1016/j.acalib.2013.03.017 [accessed 24 February 2014]; Wendy M. Duff and Joan M. Cherry, "Archival Orientation for Undergraduate Students: An Exploratory Study of Impact," American Archivist 71 no. 1 (2008): 499-529; Magia Krause, "Undergraduates in the Archives: Using An Assessment Rubric to Measure Learning," American Archivist 73, no. 2 (2010): 507-34.

3. "Primary Sources: What Are Primary Sources?" Primary Sources at Yale, Yale University website, available online at www.yale.edu/collections_collaborative/primarysources/primarysources.html [accessed 24 February 2014].

4. Elizabeth Yakel, "Information Literacy for Primary Sources: Creating a New Paradigm for Archival Researcher Education," OCLC Systems \& Services: International Digital Library Perspectives 20, no. 2 (2004): 63.

5. Carol B. Stapp, “Defining Museum Literacy,” Roundtable Reports 9, no. 1 (1984): 3-4. 
primary sources. ${ }^{6}$ Yet, none of these communities have engaged with formalized information literacy skills in the same ways as college and university libraries. Building on the efforts of college and university librarians to codify information literacy skills will help frame what primary source literacy can be. This paper argues that cultural heritage professionals need to work together to develop guidelines for primary source literacy. It reviews the literature on teaching with primary sources and concludes by suggesting some potential elements for a definition of primary source literacy as a starting point for debate and augmentation by the cultural heritage community.

\section{Information Literacy and Primary Sources}

College and university libraries have a long history of user education. Over time, the range of skills addressed in user education has grown from simple orientations to the library as a physical space to exploring larger concepts of efficiently finding and using information - often using digital tools. These skills have come to be known as information literacy. Formally recognized by libraries in the 1990s, information literacy has become widely accepted by educational institutions and accrediting bodies. ${ }^{7}$ With continued technological advances, information literacy has been supplemented by related standards over the course of the last two decades, including visual, media, computer, digital, and network literacy. ${ }^{8}$

The Association of College and Research Libraries (ACRL) released standards for information literacy in 2000. The standards divide information literacy competencies into five areas and anticipate that the information-literate student will be able to:

1. determine the nature and extent of the information needed;

2. access needed information effectively and efficiently;

3. evaluate information and its sources critically and incorporate selected information into his or her knowledge base and value system;

6. Anne Bahde, "Taking the Show on the Road: Special Collections Instruction in the Campus Classroom," RBM: A Journal of Rare Books, Manuscripts, and Cultural Heritage 12, no. 2 (Fall 2011): 75-88; Pablo Alvarez, "Introducing Rare Books into the Undergraduate Curriculum," RBM: Journal of Rare Books, Manuscripts, and Cultural Heritage 7, no. 2 (Fall 2006): 94-103; Susan Allen, "Rare Books and the College Library: Current Practices in Marrying Undergraduates to Special Collections," Rare Books and Manuscripts Librarianship 13, no. 2 (1999): 110-19; Anna Elise Allison, Connecting Undergraduates with Primary Sources: A Study of Undergraduate Instruction in Archives, Manuscripts, and Special Collections (master's thesis, School of Library and Information Science, University of North Carolina at Chapel Hill, 2005).

7. Monty L. McAdoo, Building Bridges: Connecting Faculty, Adults, and the College Library (Chicago: American Library Association, 2010), 4-5. While there is general administrative acceptance of the importance of information literacy goals, libraries, at times, have difficulty working with individual faculty members to integrate this training into their curricular instruction. See Annie Armstrong, "Marketing the Library's Instructional Services to Teaching Faculty: Learning from Teaching Faculty Interviews," in College Libraries and Student Culture: What We Know Now, eds. Lynda M. Duke and Andrew D. Asher (Chicago: American Library Association, 2012), 31-48.

8. Michael B. Eisenberg, Carrie A. Lowe, and Kathleen Spitzer, Information Literacy: Essential Skills for the Information Age, 2nd ed. (Westport, Conn.: Libraries Unlimited, 2004), 7-9. 
4. use information effectively to accomplish a specific purpose, either individually or as a member of a group; and

5. understand many of the economic, legal, and social issues surrounding the use of information, which includes accessing and using information ethically and legally. ${ }^{9}$

Although all of these competency areas can be applied while working with primary sources, only the first standard in the document specifically mentions primary sources in its expected outcomes and relates only to the ability of students to distinguish between primary and secondary sources. As a result, library-based information literacy efforts have tended to focus merely on the ability to differentiate between types of sources rather than teaching students about the access and use of these resources. ${ }^{10}$

Libraries teach information literacy in a variety of ways, including course-related instruction, drop-in sessions, first-year experience programs/learning communities, and credit-bearing courses. ${ }^{11}$ For the most part, information literacy training is limited to single instruction sessions in association with a composition or subjectbased course. ${ }^{12}$ The limitations of these instruction sessions often force librarians to focus on basic principles and general purpose tools. In some cases, librarians have attempted to embed primary source instruction in these general sessions. ${ }^{13}$ In other libraries, cultural heritage professionals actively assist with library instruction to interject information about primary sources into the information literacy curriculum. ${ }^{14} \mathrm{~A}$ few institutions have tried using credit-bearing courses to provide instruction on cultural heritage-related issues. Examples such as the "Archives, Documents, and Hidden History" course at Baruch College in New York, offered as part of their library department's undergraduate minor in Information Studies, are the exception. ${ }^{15}$

9. Association of College and Research Libraries, "Information Literacy Competency Standards for Higher Education," American Library Association, available online at www.ala.org/acrl/standards / informationliteracycompetency [accessed 2 July 2013].

10. Christy Gavin, Teaching Information Literacy: A Conceptual Approach (Lanham, Md.: Scarecrow Press, 2008): 206-08; Teresa Y. Neely, Information Literacy Assessment: Standards-Based Tools and Assignments (Chicago: American Library Association, 2006), 34-35.

11. Trudi E. Jacobson and Lijuan Xu, Motivating Students in Information Literacy Classes (New York: Neal-Schuman, 2004), 11; Ilene Rockman et al., Integrating Information Literacy into the Higher Education Curriculum: Practical Models for Transformation (San Francisco, Calif:: Jossey-Bass, 2004), 37-44.

12. For examples of subject-based library instruction curriculum, see Joel D. Kitchens, "History," in Information Literacy Instruction That Works: A Guide to Teaching by Discipline and Student Population, ed. Patrick Ragains, (New York: Neal-Schuman, 2006), 165-83.

13. Joel D. Kitchens, "Practical Help for History Instruction: Making the One-shot Count," Research Strategies 18 (2001): 67, 70 .

14. Shan Sutton and Lorrie Knight, "Beyond the Reading Room: Integrating Primary and Secondary Sources in the Library Classroom," Journal of Academic Librarianship 32, no. 3 (2006): 320-25.

15. Sandra Roff, "Archives, Documents, and Hidden History: A Course to Teach Undergraduates the Thrill of Historical Discovery Real and Virtual," History Teacher 40, no. 4 (Aug. 2007): 551-58. For a discussion of the Baruch College course content, see Trudi E. Jacobson and Lijuan Xu, Motivating Students in Information Literacy Classes (New York: Neal-Schuman, 2004), 23-39. 
While information literacy was developed as a concept within the library community, information literacy, to be effective, should be integrated into the wider university curriculum as well. Components of these standards of general applicability are generally addressed through library instruction, but discipline-specific skills may be taught or reinforced in the appropriate instructional units. Coordination between librarians and faculty elsewhere in the university is critical for preventing instructional gaps when teaching information literacy skills-particularly in the context of primary sources.

To take a familiar discipline for many cultural heritage professionals as an example, history educators often have a slightly different focus in teaching information literacy principles. Primary source instruction in history courses focuses on the third and fourth of the information literacy standards-how primary source materials are interpreted and used. Traditionally, history instruction in primary and secondary schools (as well as lower-division undergraduate courses) addresses content, not process. ${ }^{16}$ However, over the past decade there has been a growing emphasis on integrating the teaching of historical thinking skills alongside the historical narrative-providing students with the tools to understand how historical knowledge is developed. In secondary schools, this includes instruction on concrete skills related to how historians use evidence, such as citing sources, evaluating arguments and bias, and integrating sources into the student's own writing. ${ }^{17}$ Educational proponents have also advocated for the inclusion of concepts such as historical significance, continuity and change, progress and decline, and historical empathy as part of a standard curriculum. ${ }^{18}$ Similarly, at the undergraduate and graduate levels, history programs incorporate traditional methods of source criticism, evaluating sources internally and externally to identify bias and context. ${ }^{19}$

16. Michael J. Galgano, Liberal Learning and the History Major (Washington, D.C.: American Historical Association, 2007), 7-8.

17. Common Core State Standards Initiative, "Common Core State Standards for English Language Arts \& Literacy in History/Social Studies, Science, and Technical Subjects," Common Core State Standards Initiative, 61, available online at www.corestandards.org/assets/CCSSI_ELA\%20Standards.pdf [accessed 12 December 2012].

18. Stephane Levesque, Thinking Historically: Educating Students for the Twenty-First Century (Toronto: University of Toronto Press, 2008), 17.

19. Martha Howell and Walter Prevenier, From Reliable Sources: An Introduction to Historical Methods (Ithaca, N.Y.: Cornell University Press, 2001), 60-68. See also Galgano, Liberal Learning and the History Major, 7; American Historical Association Tuning Project, "History Discipline Core," American Historical Association, available online at www.historians.org/projects/tuning/HistoryDisciplineCoreInitial\%20Release_08-28-12.pdf [accessed 10 December 2012]; and Committee on Graduate Education of the American Historical Association, "The Education of Historians for the Twenty-first Century: Part 2-Foundations," American Historical Association, available online at www.historians.org/projects/ cge/2004/report/ch4.html [accessed 10 December 2012]. Mary Jo Pugh has also noted the lack of preparation for archival research in history graduate students: see Providing Reference Services for Archives \& Manuscripts (Chicago: Society of American Archivists, 2005), 51-52. 
To support this training in source criticism, history instructors often turn to published collections of primary sources for use in the curriculum. In his article "Clio in the Raw," Hugh A. Taylor traces the introduction of these volumes to as early as $1906 .{ }^{20}$ These printed works contain extracts of documents and are typically used to illustrate points described in an accompanying textbook. Cultural heritage repositories later developed their own packets of source materials for use in classes on local history. These packets generally contain preselected copies of original materials for use by students, as well as lesson plans and other pedagogical material for teachers. As cultural heritage materials have moved online, history teachers are now able to select their own documents for instruction and analysis exercises. ${ }^{21}$ At the same time, remote access has also allowed cultural heritage institutions to expand access to these packets, leading to the development of sophisticated instructional sources such as the National Archives DocsTeach tool or the University of California's Calisphere. ${ }^{22}$

While these prepackaged source materials are useful in the context of document analysis, Taylor contends that, to have a "genuine historical experience," students need access to unstructured primary source documentation. ${ }^{23}$ Source packets separate cultural heritage materials from their context, potentially reducing their value as historical evidence in a training exercise. ${ }^{24}$ As one historian recently put it,

historians do not work with "source packets," and they would never allow anyone else to select their sources for them. Historians ask questions about the past, and they seek evidence that will help answer those questions. They select the evidence themselves, and they do so precisely because of its authorship and purpose. They do not analyze sources in the ways suggested either by document-based questions or by research on sourcing, because they have no reason to work with other people's collections of documents. ${ }^{25}$

20. Hugh A. Taylor, "Clio in the Raw: Archival Materials and the Teaching of History," American Archivist 35, no. 3-4 (July/October), 318.

21. Kathleen Craver, Using Internet Primary Sources to Teach Critical Thinking Skills in History (Westport, Conn.: Greenwood Press, 1999); P. Van Fossen and J.M. Shiveley, "Using the Internet to Create Primary Source Teaching Packets," The Social Studies 91 (2000): 244-52; Adam M. Friedman, "World History Teachers' Use of Digital Primary Sources: The Effect of Training," Theory and Research in Social Education 34, no. 1 (Winter 2006): 124-41; Richard J. Cox, Janet Ceja Alcalá, and Leanne Bowler, "Archival Document Packets: A Teaching Module in Advocacy Training Using the Papers of Governor Dick Thornburgh," American Archivist 75, no. 2 (Fall/Winter 2012): 380-83.

22. Foundation for the National Archives, "The National Archives Experience: DocsTeach," Foundation for the National Archives, available online at http:/ / docsteach.org/ [accessed 10 December 2012); UC Libraries, "Calisphere: A World of Primary Sources and More," University of California, http:/ / www.calisphere.universityofcalifornia.edu/ [accessed 10 December 2012).

23. Taylor, "Clio in the Raw," 330.

24. Taylor, "Clio in the Raw," 330; Michael Eamon, "A 'Genuine Relationship with the Actual': New Perspectives on Primary Sources, History and the Internet in the Classroom," History Teacher 39, no. 3 (May 2006): 303.

25. Keith C. Barton, "Primary Sources in History: Breaking through the Myths," Phi Delta Kappan 86, no. 10 (June 2005): 749. 
History programs are also meant to provide undergraduate and graduate students with the opportunities to develop their skills in using primary sources to create historical arguments. Through capstone, thesis, or other writing projects, students are required to bring together primary sources to develop and support their conclusions. ${ }^{26}$ This type of activity addresses the fourth of the information literacy goals, demonstrating that students are able to "use information effectively."

However, this model for primary source information literacy—with librarians focusing on finding materials and historians focusing on their use — can break down in addressing research skills for primary source materials, with neither library instruction nor history programs addressing the gap. This is particularly true for cultural heritage materials, which, due to their unique nature, require a different skill set to enable their effective use. ${ }^{27}$ As caretakers of primary source materials, cultural heritage professionals are well placed to address this shortcoming.

\section{Toward a Definition of Primary Source Literacy}

To fill this gap successfully, cultural heritage professionals need to define primary source literacy clearly, considering both the application of information literacy principles to these materials and the unique skills required for using primary sources effectively. Joanne Archer, Ann Hanlon, and Jennie Levine point out that "the Information Literacy Competency Standards for Higher Education...emphasizes the importance of competence in primary sources" but note that "what is less evident is how best to educate students about these specialized sources." ${ }^{28}$ As Yakel emphasized in 2004, it is critical for cultural heritage professionals to define the "core knowledge and skill sets that would comprise information literacy for primary sources." ${ }^{29}$ Efforts to identify the elements of a definition have now been underway for thirty years or more, although beginning in the early 2000 s this discussion has become more prominent within the cultural heritage community.

\section{Artifactual Literacy}

Perhaps the longest-running discussion on the pedagogical use of primary source materials has been had among museum professionals. As early as 1984, Carol Stapp had proposed the term "museum literacy" to describe the skill set that visi-

\footnotetext{
26. Stephen D. Andrews, "Structuring the Past: Thinking about the History Curriculum," Journal of American History 95, no. 4 (Mar. 2004): 1097-098.

27. Susan Grigg, "Archival Practice and the Foundations of Historical Method," Journal of American History 78, no. 1 (June 1991): 228; Joanne Archer, Ann M. Hanlon, and Jennie A. Levine, "Investigating Primary Source Literacy," Journal of Academic Librarianship 35 no. 5 (2009): 410-420; For an example of the gap in library instruction for archival resources, see Joel D. Kitchens, "History," in Information Literacy Instruction That Works: A Guide to Teaching by Discipline and Student Population, ed. Patrick Ragains (New York: Neal-Schuman, 2006): 165-83.

28. Archer, Hanlon, and Levine, 410.

29. Yakel, "Information Literacy for Primary Sources," 63.
} 
tors would need to best engage with institutional collections. According to Stapp, one of the primary components of museum literacy was "competence in reading objects ('visual literacy')." ${ }^{30}$ Visual literacy is generally defined as "the ability to derive meaning from images of everything that we see" ${ }^{31}$ and includes observational, analytical, and interpretive skills. ${ }^{32}$ From this foundation, the museum and educational communities have expanded these literacies beyond images to objects ("object literacy") and artifacts ("artifactual literacy"). ${ }^{33}$

The importance of artifactual literacy was recognized in the archival community by Yakel and Torres in 2003 as part of their model for developing user expertise with archival and manuscript materials. In their initial article, they posited that three areas of knowledge are necessary for successfully using archival materials, including artifactual literacy, which they defined as "the ability to interpret and analyze primary sources." ${ }^{34}$ While recognizing the value of artifactual literacy to archival research, Yakel and Torres described it as being tied to general pedagogical approaches for teaching critical thinking skills and in that way not necessarily specific to primary source literacy.

However, other authors in the archival community have recognized the importance of artifactual literacy in developing a primary source-based curriculum. While not using the term "primary source literacy," in 2009 Peter Carini provided perhaps the most complete list of concepts to be addressed though archival instruction. ${ }^{35}$ His fifteen-point list includes both basic information literacy skills, such as distinguishing between primary and secondary sources, and more complex artifactual literacy skills, such as historical contextualization and evaluating the physical characteristics of source materials. Magia Krause also focused heavily on artifactual literacy skills in her definition of primary source literacy in 2010. Among the four concepts in her definition, she included artifactual and

30. Stapp, "Defining Museum Literacy," 3.

31. Center for Visual Literacy, "What Is Visual Literacy," Toledo Museum of Art, available online at www.vislit.org/visual-literacy/ [accessed 12 December 2014].

32. Although the first definition of visual literacy was offered by John Debes in 1969, there has been some debate over the term's meaning. For a discussion of the question, including various definitions, see Jennifer M. Brill, Dohun Kim, and Robert Maribe Branch, "Visual Literacy Defined-The Results of the Delphi Study: Can IVLA (Operationally) Define Visual Literacy?” Journal of Visual Literacy 27, no. 1 (Spring 2007): 47-60.

33. See Robert Bain and Kirsten M. Ellenbogen, "Placing Objects Within Disciplinary Perspectives: Examples from History and Science," in Perspectives on Object-Centered Learning in Museums, ed. Scott G. Paris (Mahwah, N.J. : Lawrence Erlbaum Associates, 2002), 145; Elizabeth Wood and Kiersten F. Latham, The Objects of Experience: Transforming Visitor-Object Encounters in Museums (Walnut Creek, Calif.: Left Coast Press, Inc., 2014), 43; Kate Pahl and Jennifer Rowsell, Artifactual Literacies: Every Object Tells a Story (New York: Teachers College Press, 2010), 2-5.

34. Elizabeth Yakel and Deborah A. Torres, "AI: Archival Intelligence and User Expertise," American Archivist 66 (Spring/Summer 2003): 52, 54.

35. Peter Carini, "Archivists as Educators: Integrating Primary Sources into the Curriculum," Journal of Archival Organization 7, no. 1 (2009): 48. 
visual skills such as observation, interpretation/historical context, and evaluation/ critical thinking. ${ }^{36}$

A similar focus on visual and artifactual literacy skills is also commonly seen in the special collections/rare books literature. Pablo Alvarez highlights the importance of allowing students to engage with the physicality of primary sources. He writes that it is important to "select some examples of how the physicality of the book, manuscript, or printed material can provide the students with new perspectives to explore specific themes" of a course. ${ }^{37}$ By treating rare books as objects, rare book librarians are able to use the multimodal literacy approaches used by museum professionals in teaching their visitors.

In their recent book Using Primary Sources: Hands-on Instructional Exercises, Ann Bahde, Heather Smedberg, and Mattie Taormina have also focused heavily on artifactual literacy skills in their effort to define primary sources. Among the main points in their definition were object or artifactual literacy skills, such as "identifying a variety of source formats and types," "observation and descriptive skills," "interpreting and analyzing primary sources," "recognizing primary sources and their often complex relationship to secondary sources," "primary source evaluation," "us[ing] them effectively as evidence," "convey[ing] their interpretations," and "understanding the legal and social issues represented" in primary sources. ${ }^{38}$

Through the acquisition of artifactual literacy skills, researchers are able to understand and contextualize the content of primary source material. They are able to "read" objects, archival records, manuscripts, and published items and to engage with them critically. As Yakel and Torres suggested, while these are transferrable skills, they are particularly important when engaging with primary source materials. Another commentator, Andrew Simpson, similarly wrote that "developing the skills and ability to interpret documents through a process of observation and evidence-based inductive reasoning should be embedded as a generic outcome in all university teaching and learning plans." ${ }^{39}$

\section{Cultural Heritage Literacy}

While the cultural heritage community has recognized the importance of visual or artifactual literacy skills to using primary sources, there remains an equal focus on skills that allow visitors and researchers to access and contextualize these materials. While these competencies may vary somewhat between repository types, there is an increas-

\footnotetext{
36. Krause, "Undergraduates in the Archives," 513-14.

37. Alvarez, "Introducing Rare Books into the Undergraduate Curriculum," 98.

38. Using Primary Sources: Hands-on Instructional Exercises, eds. Anne Bahde, Heather Smedberg, and Mattie Taormina (Santa Barbara, Calif.: Libraries Unlimited, 2014): xix-xx.

39. Andrew Simpson, "Comment," Museum Management and Curatorship 24, no. 1 (Mar. 2009): 21.
} 
ingly common understanding that, for users or researchers to understand a curated assemblage of primary sources, users need to be familiar with how cultural heritage institutions manage these materials, how the materials can be accessed, and the impact of curatorial activities on the evidential and informational value of these sources.

In a library setting, much of this training is provided through general information literacy programs that include traditional library instruction, with a focus on "providing awareness of library resources and services and demonstrating how to use them more effectively." ${ }^{40}$ This might include instruction on the history of libraries, the organization of the library and the application of call numbers, and the use of catalogs and databases. ${ }^{41}$ As noted by Bahde, Smedberg, and Taormina, special collections librarians and manuscript curators then supplement by orienting users on tools and procedures specific to their area, such as "an introduction to archival research concepts and methods, an orientation to departmental procedures and policies, and/ or a description of other relevant holdings in the collections of the department." ${ }^{42}$

The need for such repository-specific skills was also noted by Stapp in establishing her definition of museum literacy, which, in addition to visual literacy skills, included "competence in drawing upon the museum's holdings and services purposely and independently." 43 Through learning how to understand not only the artifacts the museum holds but also the framework in which they are made available, visitors would become "empowered." As Nicolette Meister and William Green have suggested, "a liberally educated person should be able to read objects, exhibitions and even institutions just as well as he or she can read a book." ${ }^{44}$

In a 2012 study for the Smithsonian, Jes A. Koepfler expanded on Stapp's definition, providing a list of skills that might be used to assess a visitor's level of museum literacy. These included "advanced organizing, engaging with staff, connecting with art, connecting with the Museum as a space, establishing a sense of ease in the environment by accessing creature comforts, spatial navigation and orientation, and terminology." ${ }^{55}$ Those who had mastered these skills were felt to have a better experience and to develop a better connection with the museum itself.

40. Monty L. McAdoo, Fundamentals of Library Instruction (Chicago: American Library Association, 2012): 3 .

41. McAdoo, Fundamentals of Library Instruction, 34.

42. Bahde, Smedberg, and Taormina, Using Primary Sources, 77.

43. Stapp, "Defining Museum Literacy," 3.

44. Nicolette Meister and William Green, "Comment," Museum Management and Curatorship 24, no. 1 (Mar. 2009): 15.

45. Jes A. Koepfler, Georgina Goodlander, Tierney Sneeringer, Bridget Callahan, and Mary Tait, "21st Century Skills, Museum Literacy, and Enjoyment in Museums: An Exploratory Summative Evaluation of PHEON at the Smithsonian American Art Museum [Technical Report]," UXR Consulting, Inc., Philadelphia, Pa., available online at http:// uxrconsulting.com/about/jes/publications [accessed 27 February 2014). 
In the archives community, Yakel and Torres also suggested that developing user expertise with archives required more than artifactual literacy skills. They posited that three areas of knowledge are necessary for successfully using archival materials: domain knowledge, artifactual knowledge, and archival intelligence. They defined archival intelligence as being composed of three components: "1) knowledge of archival theory, practices, and procedures; 2 ) strategies for reducing uncertainty and ambiguity when unstructured problems and ill-defined solutions are the norm; and 3) intellective skills, or the ability to understand the connection between representations of documents, activities, and processes and the actual object or process being represented." 46

In many regards, the components of archival intelligence described by Yakel and Torres fit well with the expectations and identified needs of the teaching faculty in disciplines such as history. For example, in a recent report from the nonprofit Ithaka $S+R$, researchers noted that "[d]iscovery is an essential part of history research," recommending that archives "offer training... in the use of archives, ...not only on the use of the campus's own archives, but on the diversity of archives that students may encounter." ${ }^{47}$ Similarly, Krause found that educators feel archivists are uniquely positioned to provide education in "(1) knowledge of primary sources and collections and (2) navigation skills." 48 These skills might include some components of a standard orientation session, but likely focus more on concepts and general tools than institution-specific mechanics.

Other aspects of Yakel and Torres's archival intelligence may not be recognized as a curricular need by educators, as has been discussed by Terry Cook and Francis Blouin in their explorations of the "archival divide." Through their writings, they have also suggested the need for researchers, particularly historians, to understand the role and impact of cultural heritage professionals in making primary sources available. In his essay, "The Archive(s) Is a Foreign Country," Cook suggested the need to educate historians about the impact of archival appraisal, processing, and other curatorial tasks on the historical record. By helping this important user group to interpret "the heavy layers of intervention and meaning coded into the record by archivists," historians will be able to engage with these sources at a deeper, more complex level. ${ }^{49}$ In a similar vein, Blouin argues for the need for "a new partner-

46. Elizabeth Yakel and Deborah A. Torres, "AI: Archival Intelligence and User Expertise," American Archivist 66 (Spring/Summer 2003): 52, 54.

47. Jennifer Rutner and Roger C. Schonfeld, Supporting the Changing Research Practices of Historians (New York: Ithaka S+R, 2012) available online at www.sr.ithaka.org/research-publications/supportingchanging-research-practices-historians [accessed 11 December 2012]: 15, 42.

48. Magia Krause, "'It Makes History Alive for Them': The Role of Archivists and Special Collections Librarians in Instructing Undergraduates," Journal of Academic Librarianship 36 no. 5 (Sept. 2010): 404.

49. Terry Cook, "The Archive(s) Is a Foreign Country: Historians, Archivists, and the Changing Archival Landscape," American Archivist 74, no. 2 (Fall/Winter 2011): 617, 631-32. 
ship on the part of academic history to comprehend the intellectual constructs that form the foundation of modern archival administration." ${ }^{50}$ Archer, Hanlon, and Levine, in their 2009 study of primary source literacy needs, also noticed a need for additional training in archival intelligence skills. Among these deficiencies, they found that students needed additional instruction to:

- develop a better understanding of the scope and definition of primary sources;

- become familiar with key terminology and specialized tools (such as finding aids); and

- understand how to use tools they may already be familiar with to locate primary sources and develop effective search techniques for these tools. ${ }^{51}$

In the same way, in a 2010 article, Krause included archival intelligence skills as well as artifactual literacy in her definition of primary source literacy. Among her four main concepts, she listed research skills as critical to using archival materials effectively. ${ }^{52}$ This entailed many of the concepts previously identified as archival literacy. Through the activities used in the session she described, Krause attempted to shift the content from procedural concerns to conceptual knowledge, an approach she had earlier described as providing a "deeper understanding of archives and manuscripts through terminology, description, and interpretation of documents." ${ }^{53}$

Most recently, Bahde, Smedberg, and Taormina also included a number of repository-specific competencies within their definition of primary source literacy. These included navigation and searching skills, such as "understanding the key features and operations of [access] tools" and "learning to generate relevant keywords," and usage considerations like handling materials and the "importance of reading room guidelines and access procedures..$^{54}$

Based on this literature, some repositories have begun to modify their instructional practices to integrate the idea of cultural heritage literacy. Michael J. Paulus of Whitman College has noted through his experiences that teaching students "to

50. Francis X. Blouin, Jr., "The Evolution of Archival Practice and the History-Archival Divide," in Controlling the Past: Documenting Society and Institutions, ed. Terry Cook (Chicago: Society of American Archivists, 2011): 327. Blouin expands on these themes in his book, cowritten with William G. Rosenberg, Processing the Past: Contesting Authority in History and the Archives (New York: Oxford University Press, 2011).

51. Archer, Hanlon, and Levine, 419.

52. Krause, "Undergraduates in the Archives," 513-14.

53. Krause, "Learning in the Archives," 244.

54. Bahde, Smedberg, and Taormina, Using Primary Sources, $\mathrm{xix}-\mathrm{xx}$. 
'think like an archivist or special collections librarian' is a valuable critical skill." 55 At the University of Minnesota, in supporting a historical methods course, archivists developed "a program of three related instructional modules designed to attract interest, convey key ideas about primary sources, introduce archival theory and practice, and develop learning and research skills." ${ }^{56}$ Meanwhile, archivists at the University of Nebraska-Lincoln changed their approach to orientation sessions completely, from "providing a brief tour of the collections and resources we felt would elicit student interest to explaining to students how to use collections, what they would need to do to use the collections, how we run the department, and what kind of care and handling would be required for the use of the materials." ${ }^{57}$

\section{Additional Skills}

While most authors have identified artifactual literacy and cultural heritage literacy skills as being central to primary source literacy, additional areas of expertise have been identified in the literature that may be important for using primary sources effectively. In the archives community, Yakel and Torres posited that, in addition to artifactual knowledge and archival intelligence, domain knowledge was critical for researcher access to archives. They defined domain knowledge as "an understanding of the topic being researched." 58 Bahde, Smedberg, and Taormina have similarly sought to introduce historical thinking skills into their definition of primary source literacy, including the concepts "cultivation of historical imagination," "development of historical empathy," "curiosity about the past," and "appreciation for historical materials." ${ }^{59}$ In the museum community, John Pedro Schwartz has advocated for a diversified model for museum literacy, expanding the scope of literacies required for understanding museums to include not only visual literacy, but also verbal, technological, social, and critical literacy as needed skills for "understanding communication in the museum." ${ }^{60}$

55. Michael J. Paulus, Jr., "What Is Primary: Teaching Archival Epistemology and the Sources Continuum," in Past or Portal? Enhancing Undergraduate Learning through Special Collections and Archives, eds. Eleanor Mitchell, Peggy Seiden, and Suzy Taraba (Chicago: ACRL, 2012), 80.

56. Ryan Bean and Linnea M. Anderson, "Teaching Research and Learning Skills with Primary Sources: Three Modules," in Past or Portal? Enhancing Undergraduate Learning through Special Collections and Archives, eds. Eleanor Mitchell, Peggy Seiden, and Suzy Taraba (Chicago: ACRL, 2012), 157.

57. Peterson Brink, Mary Ellen Ducey, Andrew Jewell, and Douglas Seefeldt, "Teaching Digital History through the University Archives: The Case of Nebraska U: A Collaborative History," in Past or Portal? Enhancing Undergraduate Learning through Special Collections and Archives, eds. Eleanor Mitchell, Peggy Seiden, and Suzy Taraba (Chicago: ACRL, 2012), 186.

58. Elizabeth Yakel and Deborah A. Torres, "AI: Archival Intelligence and User Expertise," American Archivist 66 (Spring/Summer 2003): 52, 54.

59. Bahde, Smedberg, and Taormina, Using Primary Sources, xix-xx.

60. John Pedro Schwartz, "Object Lessons: Teaching Multiliteracies through the Museum," College English 71, no. 1 (Sept. 2008): 29-30. 


\section{Defining Primary Source Literacy}

While cultural heritage professionals have identified components of primary source literacy, there has not yet emerged a comprehensive definition. This is, in part, due to prevailing attitudes that "a set of primary source literacies is difficult to imagine, in part because of the diversity of formats and methods for finding and using digital and archival primary sources, the myriad definitions of and approaches to primary sources across disciplines, and the variability of contexts we face as librarians." ${ }^{61}$ However, this very diversity is one of the strongest arguments for developing a comprehensive definition of primary source literacy. Cultural heritage professionals need to have a common framework to draw upon as they adapt the teaching of primary source literacy to their individual contexts. They also need to be able to effectively assess their educational outreach activities. Bahde, Smedberg, and Taormina have argued that "establishing primary source literacy standards that articulate these particular differences would empower special collections and archives professionals to generate more structured, effective, and meaningful assessments of instruction; demonstrate the unique value they bring to their institutions; and participate more fully in the assessment efforts that are now commonplace in higher education and other organizations." 62

Establishing primary source literacy standards involves defining what cultural heritage professionals mean by primary source literacy and then developing appropriate learning outcomes and learning activities. A full definition of primary source literacy will need to include both components of broader information literacy goals, as well as specific training for the unique materials found in cultural heritage repositories. Primary source literacy should describe the skills and knowledge that allow individuals to locate, evaluate, and use cultural heritage materials effectively. Drawing on the literature reviewed above, we have concluded that information literacy goals applicable to primary source materials include: $:^{63}$

- $\quad$ understanding the variety of tools available for locating cultural heritage materials and how to use those tools. These tools include library catalogs, finding aid databases, and collection guides;

61. Melanie Maksin and Nina Clements, "Beyond the Physical Archive: Imagining Primary Source Literacies in the Digital Age," Imagine, Innovate, Inspire: The Proceedings of the ACRL 2013 Conference (2013), available online at www.ala.org/acrl/sites/ala.org.acrl/files/content/conferences/confsandpreconfs/2013/papers/MaksinClements_Beyond.pdf [accessed 7 November 2014].

62. Bahde, Smedberg, and Taormina, Using Primary Sources, 157.

63. While some authors have noted a resistance among cultural heritage professionals, especially archivists, to apply the term "information literacy" to their instruction efforts, we would argue that the profession would get greater traction by both injecting cultural heritage concepts into library information literacy programs and by building off university acceptance of the idea of information literacy in integrating cultural heritage concepts into the teaching of the disciplines. See also Krause, "It Makes History Alive for Them,"” 405; Carini, "Archivists as Educators," 47. 
- $\quad$ understanding and being able to articulate the difference between primary and secondary sources;

- understanding the importance of contextualizing information extracted from cultural heritage materials;

- understanding the political, legal, and ethical issues surrounding the use of cultural heritage materials; and

- understanding how to apply critical thinking skills to cultural heritage materials.

A strong definition of primary source literacy will also need to incorporate concepts specific to using cultural heritage materials. Users of primary sources need to understand the impact that preservation processes undertaken by cultural heritage institutions, as well as the presentation of the materials, have on the meaning of the collections themselves. Goals relating to this area might include:

- developing cultural heritage literacy, ${ }^{64}$ including an understanding of the various theories undergirding the work of cultural heritage professionals, as well as how those theories inform practice and procedures;

- understanding how cultural heritage professionals interact with the materials under their care, and how their interventions impact primary sources; and

- understanding how labels and other displays are used by cultural heritage professionals to create a narrative or argument.

Finally, primary literacy goals should promote understanding of the physical aspects of these materials as information artifacts and not merely information objects, such as:

- understanding the context of the source's physical creation, including technological processes employed in its creation;

- understanding the implications of using surrogates of primary source materials; and

- understanding how to appropriately handle primary source materials.

One of the challenges that cultural heritage professionals will face will be taking the broad primary source literacy concepts described above and making concrete learning outcomes from them.

64. Our vision for cultural heritage literacy is based heavily on the model of archival intelligence put forth by Deborah Torres and Elizabeth Yakel. 
Primary source literacy is an important skill and knowledge set for those coming to cultural heritage repositories, and one that students need to succeed in many disciplines. While in some ways it is an extension of information literacy, it goes beyond this to include a conceptual understanding of the sources-requiring a deeper engagement. This fact is recognized by cultural heritage professionals and other educators, but helping students to develop these skills successfully will require wider collaboration.

The Rare Books and Manuscripts Section (RBMS) of the Association of College and Research Libraries (ACRL), the Society of American Archivists, and the American Association of Museums have a unique opportunity to shape the educational experience of countless students by working cooperatively to develop primary source information literacy standards, particularly with the recent creation of an SAA-ACRL/RBMS Joint Task Force on the Development of Guidelines for Primary Source Literacy. The following list is an attempt to begin articulating some of the key components that these guidelines should address. The list is not meant to be prescriptive, but rather a starting place for further discussion.

In an interdisciplinary, higher education environment, an individual who is literate in primary sources will be able to:

- $\quad$ use primary sources effectively;

- $\quad$ find and access needed primary sources effectively and efficiently;

- evaluate primary sources critically;

- interpret and analyze the meaning of primary sources;

- determine the nature and extent of primary sources needed for a given project;

- understand the ethical, legal, social, and economic issues surrounding the creation and use of primary sources;

- access and use primary sources ethically;

- understand the nature of primary sources and their creation;

- determine the context of the source's physical creation;

- understand the impact of cultural heritage professionals on the meaning of primary sources; and

- handle primary source materials appropriately.

Each of these components will need to be further developed and then paired with appropriate learning outcomes that can be used to develop learning activities.

Learning outcomes will need to focus on students' ability to use cultural heritage materials in a variety of contexts to enhance their educational experiences. Poten- 
tial learning outcomes developing out of primary source literacy standards could include:

- demonstrating an understanding of cultural heritage literacy through the application of research skills, cultural heritage principles and theory, and cultural heritage practices to your own research;

- locating primary source materials in local and national databases, indexes, and other utilities;

- demonstrating the ability to judge and differentiate between primary and secondary sources;

- identifying methods used by your discipline to analyze and incorporate primary sources into your research;

- determining subject, narrative, and research application of primary sources to demonstrate the analytical skills needed to conduct research; and

- demonstrating the ability to provide proper research documentation.

Learning outcomes, such as the ones mentioned above, create a powerful way to communicate the value of cultural heritage materials to educators. They are concrete actions that have a direct impact on students' ability to successfully navigate the modern world. When these learning outcomes are paired with appropriate learning activities (many of which have already been developed in the profession), cultural heritage professionals are able to demonstrate the value proposition of integrating cultural heritage materials into the curriculum.

As Bahde, Smedberg, and Taormina pointed out, the development of primary source literacy standards will "create opportunities to collaborate with others more effectively and to assert a place within the broader educational discourse of these environments." ${ }^{65}$ We couldn't agree more. It is our hope that the cultural heritage community will build upon the definition of primary source literacy that we have proposed to create learning outcomes and related learning activities, which can facilitate dialogue and collaboration with educators at our various institutions. 